\title{
Imperial Factors in the Rise of Nationalism In Nigeria
}

\author{
${ }^{1}$ Victor I. Lukpata, ${ }^{2}$ Andeshi Christopher A. \\ ${ }^{I}$ (Ph.D), Dada A. Olorunfemi, Elimian Alexander Department Of History \& Diplomatic Studies Federal \\ University Wukari, Taraba State, Nigeria \\ ${ }^{2}$ Department Of Political Science Federal University Wukari Taraba State, Nigeria
}

\begin{abstract}
British colonialism created Nigeria by joining diverse peoples and regions in an artificial political entity along the Niger River. The nationalism that became a political factor in Nigeria during interwar period derived both from an older political particularism and broad pan-Africanism rather than from any sense among the people of a common Nigerian nationality. The goal of activists initially was not self-determination but increased participation on a regional level in the governmental process. Inconsistencies in British policy reinforced existing cleavages based on regional anniversaries, as the British tried both to preserve the indigenous cultures of each area and to introduce modern technology and Western political and social concepts. Modern nationalists in the south, whose thinking was shaped by European ideas, opposed indirect rule, as they believed that it had strengthened what they considered an anachronistic ruling class and shut out the emerging westernized elite. The nationalists were critical of colonialism for its failure to appreciate the antiquity, hidness and complexity of indigenous cultures. They invited self government charging that only colonial rule presented such oppressive forces in Nigeria. the focus of this article is to assess the imperial factors in the rise of nationalism in Nigeria. Historical descriptive approach was adopted in the conduct of this research.
\end{abstract}

Key words: Colonialism, Nigeria, imperial, Niger River, nationality.

\section{Introduction}

The concept of nationalism would be fully appreciated if we have an indebt understanding of what is a nation, nation-state and a state. This is so because nationalism as a concept is not independent of the legal entities aforementioned. Thus, we shall look into these concepts - nation, Nation-State, state and then nationalism before we undertake an analysis of the topic under consideration which is 'the imperial factors in the rise of nationalism in Nigeria."

\section{Clarification Of Concepts}

A nation, of course, includes tangible people, but what creates a nation are less tangible elements such as similarities among the people, a sense of connection, and a desire of the people to control themselves politically.

SIMILARITIES Are The First Of The Elements Of A Nation. Thus, A Nation Is Defined As A "Group Of People Who Feel Themselves To Be A Community Bound Together By Ties Of History, Culture And Common Ancestry (Kellas, 1991:2). Often A Nation Shares Certain Similarities. These May Be Demographic Characteristics, Such As Language, Race And Religion. Or The Similarities May Be A Common Culture Or Historical Experiences. When Such Factors Are Strongly Present, The Formation Of The Nation Preceeds That Of The State,

A FEELING OF COMMUNITY Is The Second Element That Helps Define A Nation. Perception Is The Key Here. For All The Similarities A Group Might Have, It Is Not A Nation Unless It Feels Like One. What This Means Is That Those Within A Group Must Perceive That They Share Similarities And Are Bound Together By Them (Guibarnau, 1996:49).

A DESIRE TO BE POLITICAlly SEPARATE Is The Third Element That Defines A Nation. What Distinguishes A Nation From An Ethnic Group Is That The Nation, Unlike The Ethnic Group, Has A Desire To Be Self-Governing Or At Least Autonomous (Routine, 1977:140).

\section{NATION - STATE}

A Nation - State Is, In Theory, The Natural Outgrowth Of A Nation's Desire To Have Its Own State And To Govern Itself Independently. The Nation - State Is Represented By Many Symbols, Such As Flags, National Anthems Or Animals (Eagles, Bears, Dragons). It Is The Object Of Patriotic Loyalty, And Most People View It As The Highest Form Of Political Authority (Bras, 1992'8). 
In Practice The Nation - State Concept Diverges From The Ideal In Two Ways. Indeed, Some Scholars Prefer The Term National State To Emphasize The Idea Of A State Driven By Nationalism. The First Inconsistency In The Idea Of A Nation - State Is That Many States Contain More Than One Nation. Nigeria Is A Classic Example Of A Nation - State Where Many Nations Such As Ibo, Yoruba, Hausa, Efik, Ibibio, Tiv And So Forth Exist.

\section{State}

A State Is A Territorially Defined Political Unit That Exercise Ultimate Internal Authority And That Recognize No Legitimate External Authority Over It. States Are The Most Recognized And Revered Of The Political Organizations. Thus It Is A Major Actor In International Relations. Whether Large Or Small, Rich Or Poor, Populous Or Not, States Share All Or Most Of Six Characteristics: Sovereignty, Territory, Population, Diplomatic Recognition, Internal Organization And Domestic Support (Rouke, 1997:1899).

\section{Nationalism}

Nationalism Is An Ideology That, At Its Core, Holds That The Nation, Embodied In Its Agent, The Sovereign Nation - State, Should Be The Only Object Of The Political Loyalty Of Individuals. Nationalism Grows From The Sense Of Community In That "Feeds On Cultural Differences" And Turns Them Into A Principle Of Political Loyalty And Social Identify" (Gellner, 1995,:2). As Such, Nationalism Merges The Concepts Of State, Nation And Nation-State In A Way That Is Personally Related To Citizens. This Occurs When Individuals:

(a) "Becomes Sentimentally Attached To The Homeland"

(b) "Gain A Sense Of Identity And Self-Esteem Through Their National Identification, And

(c) Are "Motivated To Help Their Country" (Druckman, 1994:44).

\section{The Imperial Factors In The Rise Of Nationalism In Nigeria}

The Imperial Factors In The Rise Of Nationalism In Nigeria Is Analyzed In The Political, Economic, Social And Religious Spheres As Follows:

\section{Political Sphere}

Undemocratic Colonial Constitutions: It Is A Statement Of Fact That The Colonial Constitutions Were Undemocratic. A Classic Example Is The Richard' Constitutions Of 1946 Which Provide For A Legislative Council Whose Jurisdiction Was Country Wide. Unofficial Members Were Also Nominated In The Centre And In The Regions. In The Central Legislature, There Were Sixteen Official Members In The Ratio Of Thirteen ExOfficio And Three Nominated Members. There Were 28 Unofficial Members In The Ration Of 4 Elected To 24 Nominated Or Indirectly Elected Members. The Regional Councils In The West And East Had A Similar Pattern. The Constitution Was To Remain In Force For 9 Years, Subject To United, Review After Three And Six Years Operation (A.A. Boahan, 1977:201).

The Richard's Constitution Was Opposed By Many Different Groups And Political Parties In The Country. The Parties Stated That The Constitution Should Not Only Seek To Secure Greater Participation By Nigerian In Discussion Of Their Own Affairs, But It Should Enable Them To Secure Greater Participation In The Management For Their Own Affairs. The Continued Practice Of Nomination Of Members Was Bad And Fell Short Of The Recognized Democratic Way Of Election By Adult Suffrage. Of Their Own Affair. The Continued Practice Of Nomination Of Members Was Bad And Fell Short Of The Recognized Democratic Way Of Election By Adult Suffrage.

\section{National Council Of Nigerian Citizens}

The (NLNC) Observed That The System Of Nomination Has Not Encouraged The Cultivation Of A Sense Of Responsibility To Any Constituency By Nominated Members And Has Tended To Create A Feeling Of Frustration Of The People Who Were Forced To Conclude That Since A Nominated Member Is Not Usually A Popular Choice And Cannot Be Guaranteed To Serve His Constituency Loyally And Faithfully, His Presence In The Legislative Council Was Extraneous, So Far As The Interests Of The People Of Nigeria Are Concerned. The System Of Nomination Was Therefore, An Abnormally And So A Seed Was Sown For The Rise Of Nationalism In Nigeria.

The Fact That Only Four Members Were To Be Elected By Adult Suffrage As Was The Caseunder The Clifford Constitution Of 1922, Had Exposed The British Government To The Criticism That From The Year 1922 To The Year 1946, Nigerians Made No Advances At All Towards Any Qualification In Election, By Adult Suffrage Of Those Who Represent Interests In The Legislative Council.

The Constitutional Proposal Created A False Impression Of Providing For An Unofficial Majority When In Fact The "Unofficial" Where Either Chiefs, Who Were Officials Appointed By The Government Or 
Their Nominees. According To The Contention Of Political Parties Vested Interests Such As Mining, Banking, Shipping, Commerce And Industry, Should Not Be Counted As Unofficial Members And Should Not Be Represented At All Because The Country Should Not Allow Those Who Were Energetically Concerned In The Exploitation Of Its Agricultural, Forest And Mineral Resources To Exercise Legislative Power As A Matter Of Privilege; It Should Also Not Allow Those Who Have Established Monopoly In Its Commercial, Banking, Shipping And Mining Activities To Exercise Political Power As A Special Privilege, The Political Parties Contended. The National Council Of Nigerian Citizens (NLNC) Added:

"This Country Should Not Condone The Stultification Of Its Indigenous Political Philosophy By Giving Special Representation To Any Particular Stratum Of Any Section Of Its Co mmunity. This Country Should Not Allow The Interests Of Immigrant Races To Be

Paramount Over Those Of The Indigenous Races." (Ali A.M. 1984:36)

When The British Government Decided To Implement The Constitution Inspite Of The Widespread Opposition To It, The National Council Of Nigerian Citizens (NCNC) Decided In 1946 To Sent A Delegation To London, Not Only To Oppose The Constitution But Also To Request Definite Clarification Of AngloNigerian Relations On The Basis Of Treaty Obligations And Protectorate And Any Other Matters Relevant To The Progress And Welfare Of Nigeria (A.A. Boahon, 1977:201).

\section{Destruction Of The Traditional Administrative Values}

Until 1914 When The British Colonialists Amalgamated Southern And Northern Protectorates What Is Today Known As Nigeria Was Made Up Of Various Groups With Differential Governmental And Social Systems As In Hausa - Fulani Emirates In The North, Oyo Empire In The South-West And Ibos Republican Government In The South East. Due To Lack Of Qualified Personnel Among Other Factors, Indirect Rule Was Adopted As A System Of Governance. The Consequence Of Colonial Invasion Was The Destruction Of The Traditional Administrations Of Various Political Administrations Of The Aforementioned Political System. Thus, When The National Congress Of British West Africa (NCBWA) Was Formed In 1919 Most Aggrieved People Joint Hands To Demand For Their Rights For Political Participation With A View To Gaining Their Lost Independence In The Foreseeable Future. So, Among Other Things, The Congress Demanded That The Appointment And Deposition Of Chiefs Should Be Controlled By The African King Makers. This Is So Because, Colonial Administration Enacted A Bill That Placed The Control Of Chiefs Under It.

Therefore, The National Congress For British West Africa Sprang Up As A Nationalist Response Against The Destruction Of Traditional Administrations Of The People Known Today As Nigerians By Imperialist (J.A. Langleyu 1973. 153).

\section{Economic Exploitation Of The Agricultural Resources:}

\section{Economic Sphere}

It Should Be Noted That The British Government Believe That The Economics Of The Colonies Should Be Tied To Those Of The Imperial Power Just For The Benefit Of The Imperial Power. For Example, According To The Policy Tagged "Colonial Pact" The Colonies Must Provide Agricultural Export Crops For The Imperial Country, And Buy Its Manufactured Goods In Return. This Situation Led To Economic Exploitation Of The Colonies By Britain. For Instance, After The First World War, The British Placed Special Taxes On Palm Oil Going To Germany And In The 1930s Excluded Japanese Cotton Cloth From Colonies Where It Was Underselling Her Own.

The Nigerian Press Was Quick To Point Out That While Africans Were Now Forced To Buy HighPriced English Cloth, Britain Continued To Buy Cheaper Norwegian Whale - Oil, In Preference Of Nigeria Palm Oil. When There Was A Burden To Bear, It Was The Colonies That Bore It (Webster, 1980:223).

TAXATION: One Of The Purpose Of The Colonial Taxation System Was To Provide Requisite Funds For Administering The Colony As A Field Of Exploitation. Europe Colonizers Ensured That Nigerian Paid For The Upkeep Of The Governors And Police Who Oppressed Them And Served As Watch Dogs For Private Capitalists. Indeed., Taxes, According To Rodney, 1972: 180 Ware Levied During The Colonial Administration With The Aim Of Allowing The Colonial Powers To Recover The Costs Of The Armed Forces Which They Dispatched To Conquer Africa. In Effect, Therefore, The Colonial Governments Never [Put A Penny Into The Colonies. All Expenses Were Met By Exploiting The Labour And Natural Resources Of The Continent (Rodney, 1972:179).

FORCED LABOUR: The Simplest Form Of Forced Labor Was That Which Colonial Governments Exacted To Carry Out Public Works. Labour For A Given Number Of Days Per Year Had To Be Given Free For These Public Works - Building Castles For Governors, Prisoners For Africans, Barracks For Troops, And Bungalows For Colonial Officials. A Great Deal Of This Forced Labour Went Into The Construction Of Roads Railways And Ports To Provide The Infrastructure For Private Capitalist Investment And To Facilitate The Export Of 
Cash Crops. For Instance, The Railway Which Stated At The End Of The $19^{\text {th }}$ Century Required Forced Labour From Thousands Of Peasants Driven From The Villages.

The Hard Work And Appaling Conditions Led To The Death Of A Large Number Of Those Engaged In Work On The Railway. In The British Territories, This Kind Of Forced Labour Including Juvenile Labour Was Wide Spread Enough To Call Forth In 1923 A Native Authority Ordinance Restricting The Use Of Compulsory Labour For Porterage, Railway And Road Building. More Often Than Not, Means Were Found Of Circumventing Legislation. An International Forced Labour Convention Was Signed By All Colonial Powers In 1930, But Again It Was Flouted In Practice Thereby Encouraging Nationalist Agitations For The Attainment Of Independence (Rodney, 1972:1981).

\section{Social Sphere}

The Determinant In Race Relations Which Accompanied Effective British Presence In Nigeria Was An Important Source Of Grievance In The Social Sphere. Although Race Relations Were Already Bad In The $19^{\text {th }}$ Century, By The $20^{\text {th }}$ Century They Were Worse. The First Half Of The $20^{\text {th }}$ Century Witnessed An Increase In The Physical Separation Of The Two Races. Separate Residential Area Were Established For Europeans Not Only In Lagos But Throughout The Country. The European Reservations Where Generously, Provided With Amenities - Good Roads, Good Water Supply, Electricity And Other Comforts Of Life, While The African Sections Were Generally Left In Squalor. What Was Yet More Irritating Was That The Money Spent On Providing Comfort For The Whites Was The Taxpayers, While The Taxpayers Themselves Derived Little Benefit (Obaro Ikime, 1980:551)

Furthermore, Nigerians Were Irritated By The Fact That The Colonial Administration Was Unwilling To Provide Adequate Educational Facilities Until The Post-Second World War Period Education Was Left Mainly In The Hands Of The Christian Missionaries Who, Despise Their Efforts, Did Not Achieve Much Because Of Inadequate Finance And The Basic Reason Underlying Their Educational Programme. Their Educational Activities Were Not Geared To Provide High Level Manpower But Were Directed To Provide Their Converts With Basic Education So That They Would Be Able To Read And Write And Understand The Basic Christian Teaching.

The Failure Of The British Colonial Administration To Provide Education Was Accurately Reflected In The 1988 Report Of The Board Of Education For The Southern Provinces Of Nigeria.

"This Country Is In An Invidious Position Of Providing Fewer Opportunities In Regard To

Education Than Any Other British Possessions In Africa. And Yet The Youths Of The Country Are Not Lacking In Educable Capacity" (Department Of Education, Annual Report 1938:8).

The Inability Of The Administration In Providing Education For Nigerians Became A Factor In The Rise Of Nationalism In Nigeria.

\section{Religious Sphere}

Colonialism Did Not See Anything Good In The Noble Religion Of The People. Thus, Christianity Was Introduced As A Replacement, Thereby Exposing The People To Imperial Religion. This Could Be Confirmed In The Words Of George Nicol When He Said:

I Have No Other End In View But Gory Of God ....The Salvation Of My Soul And That Of My Fellow Creatures. I Am Deeply Convinced That If Africa Could Be Raised From Its Present Degraded State Of Barbarism, Superstition And Vice, To Any Equal With The Civilized World, Recourse Must Be Had To The Native Agencies. Africans Themselves Must Be The Principal Harbingers Of Peace. (George Nicol, In Henry S., 1969:128).

The Natives Did Not Take The Imposition Of Christianity On Them With Levity. It Was In Protest To This Situation That A Patriotic Nigerian, Okonlwo In Defence Of The Traditional Societal Values Murdered A White Missionary And Committed Suicide In Achebe's (Things Fall Apart.)

\section{Conclusion}

In Conclusion, The Imperial Factors In The Rise Of Nationalism In Nigeria Are Limited In This Article To Political, Economic, Social And Religious Spheres. Therefore, It Implies That There Are Other Prevalent Factors In The Rise Of Nationalism In Nigeria. 


\section{References}

[1] A.A. BOAHEN (ED.) (1977) Pan-African Protest: West Africa Nd The Italo Ethiopian Crisis 1934 - 41, Longman Group Ltd., London.

[2] Ali A. Mazrui, Michael Tidy (1984) Nationalism And New States In Africa, Heinemann Educational Books Ltd., London.

[3] David Glodsworthy (1971) Colonial Issues In British Politics 1945 - 1961, Oxford University Press, London.

[4] Frederick Henry (1944) Nationality In History And Politics, London,Routledge And Kegan Paul Ltd. Broading House.

[5] Henry S. Wilson (1969) Origins Of West African Nationalism, Macmillan, London.

[6] J.A. Longley (1933) Pan-Africanism And Nationalism In West Africa 1900-1945, Oxford

[7] J.B, Webster Et Al (1967) West Africa Since 1800: The Revolutionary Years, Longman Group Ltd., London

[8] James S. Coleman (1958) Nigeria Background To Nationalism University Of California Press, London

[9] Kannan K. Nair (1989) Politics And Society In South Eastern Nigeria 19541-1906, Afrian - Fed. Publishers Ltd, Onitsha, Nigera.

[10] Walter, Rodney (1972) How Europe Underdeveloped Africa. Bogle - Louverture Publications, London. 